\section{Australian research grant awards remain static}

Australian researchers-despondent in the wake of another slide in the success rate for National Health and Medical Research Council (NHMRC) grant applications-are looking to the federal government for a positive response to the first comprehensive review of the biomedical research sector since the 1970s, the 'Wills Report,' which was released on December 10th.

Officially titled the Health and Medical Research Strategic Review, the Wills Report is a discussion paper pulled together by a 12 member committee headed by Peter Wills. It warns that while Australia spends AUS\$28 (US\$17) per capita on medical $R \& D$, the Organisation for Economic Co-operation and Development average for developed nations is around AUS\$66 per capita. The report al so identifies other barriers to Australia making headway in the biomedical revolution, such as a crippling tax regime for R\&D companies.

The Wills Report was released three weeks after the health and medical research grants for FY99 wereannounced. These funds-favoring research into cancer, cardiovascular disease and neuroscience-are distributed by the NHMRC in its capacity as the nation's leading health and advisory research body. Federal health minister Michael Wooldridge, described the funding as the "lifeblood" of the research community: AUS\$46 million was made available for new grants on 353 projects, and AUS $\$ 116$ will fund 833 existing projects.

However, key lobbyists such as Australian Society for Medical Research (ASM R) president Steven Wesselingh say this blood is being drained: although the number of grants available has barely fluctuated over the past decade, more researchers are competing for them.

In 1990, 353 grants were successful out of 1,060 submitted-a success rate of 33 percent. This year the same number of grants was awarded from a field of 1,435 , thus reducing the success rate to 24.6 percent. "If you get less than 25 percent you're really going to rip the heart out of the research community," says Wesselingh. NHM RC research committee chairman Professor Warwick Anderson concedes that "once you get to very low success rates you run the risk that people get demoralized, get out of research, or start looking for greener pastures."

ASMR secretary Judy Halliday confirms that it is getting harder to obtain a grant: the 'cut-off point' or NHMRC-awarded rank out of ten below which an application fails has crept steadily upwards from 7.6 in 1991 to 8.1 this year. "Many good, international ly competitive grants are not getting funded," says Halliday.

NHMRC research chairman Warwick Anderson says that although fewer projectshad been funded this year, those that were successful would get moremoney for a longer period in a bid to consolidate the research base. And on the eve of the budget announcement, Anderson voiced concern that poor funding of Australian research puts the country behind in the new era of molecular biology and genomics research. While he does not want to see "all the eggs in that basket," Anderson warns that the funding available now is spread too thin. "We need to do a whole lot more if we're going to ride that biotechnology wave, and that means more government, private and charitable money for research," he told Nature Medicine.

At least the NHM RC has evidence that it is picking winners: a new bibliometric study to be released this month by Australian National University researchers Linda Butler and Paul Bourke shows NHMRC-backed research is cited disproportionately often in international publications. Of publications in the top onepercent (those cited by at least 60 other papers), two percent of researchers were

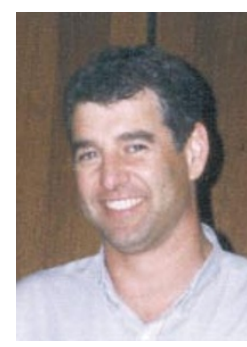

Steve Wesselingh funded by the NHMRC, and ten percent of authors in the top five percent of papers were NHMRC-funded. "We're reassured our mechanisms do identify some of the best Australian research and that's recognized internationally by the citations in those papers," says Anderson.

Not surprisingly, the research community has backed Wills' call for NHMRC funding to be doubled in five years, and for theappointment of a full-time paid chief executive officer to run the organization, replacing the current part-time honorary chairman. The document is open for consultation until April, after which the government will prepare its response.

RAda Rouse, Brisbane

\section{Researchers ben efit at BMS award night}

At a ceremony at New York's famous Pierre Hotel last month, Bernard Roizman, professor of Virology at the University of Chicago, received a personal check for $\$ 50,000$ from the pharmaceutical company, Bristol-Myers Squibb (BMS), as winner of the company's Distinguished Achievement Award in Infectious Disease Research. David Ho, scientific director and CEO of the Aaron

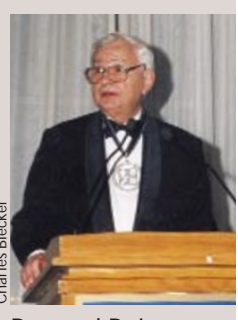

Bernard Roizman
Diamond AIDS Research Center, New York, and Gordon Archer, professor of medicine at Virginia Commonwealth University, both received research funds of $\$ 500,000$ over five years.

The evening marked the last in a series of six annual award nights in different disciplines for 1998: Distinguished Achievement Awards for cancer (Michael Sporn), cardiovascular (Philip Majerus), neuroscience (Richard Axel), nutrition (George Beaton) and orthopedic research (William Cole) were also made last year, along with two additional research prizes in each category. Ho told Nature Medicine that the BMS research funds are unique because they are given truly with "no strings attached."

Roizman is known for his work on herpes simplex virus (HSV). He mapped the HSV genome, developed recombinant DNA techniques that reveal the role of specific genes in the viral life cycle and laid the groundwork for current efforts to develop a vaccine against the virus.

Roizman accepted his award graciously, and used the occasion to voice his belief that although scientific training has improved since his graduate school days, it may have "gone too far." He declared that the system is creating "a cadre of professionals with few outstanding scientists in their midst," a process that is "becoming more and more evident as new faculty members with excellent records of publications...flounder for several years as they become fully independent." He called for an overhaul of graduate education to make it a true research education "rather than a source of dedicated cheap labor."

Karen Birmingham, New York 